\title{
IDEOLOGI DAN IDENTITAS MASYARAKAT SUNDA DALAM ROMAN CARIOS AGAN PERMAS KARYA JOEHANA (Pendekatan Kritik Poskolonial)
}

\author{
Arif Ali Abdilah, Retty Isnendes \\ Prodi. Pendidikan Bahasa dan Budaya Sunda \\ SPs Universitas Pendidikan Indonesia \\ Pos-el: arifabdilah89@gmail.com; retty.isnendes@upi.edu
}

\begin{abstract}
Abstrak
Penelitian ini bertujuan mendeskripsikan ideologi dan identitas masyarakat Sunda yang tercermin dalam karya sastra, khususnya roman. Deskripsinya berkaitan dengan pengaruh dan perubahan ideologi dan identitas sebab-akibat adanya kolonialisme. Untuk dapat menguraikan hal tersebut, maka dalam tulisan ini digunakan pendekatan kritik poskolonial, dengan menggunakan metode deskriptif-analitik. Untuk menganalisis data digunakan teknik fokalisator dan teknik interpretasi. Hasilnya menunjukkan bahwa dalam roman Carios Agan Permas, setiap kelas sosial masyarakat memiliki ideologi yang berbeda-beda. Bagi kelas kuasa, ideologi digunakan untuk mempertahankan kohesi sosial dan memperkuat kekuasaan. Ini terepresentasikan oleh subjek Haji Serbanna dan Imas. Bagi kelas tertindas, ideologi digunakan sebagai bentuk perlawanan. Bentuk ideologi ini hadir dalam diri Ambu Imba dan Otong. Dalam roman ini terdapat juga ideologi kelas kuasa, namun dalam praktiknya digunakan untuk melakukan resistensi sekaligus melindungi kelas tertindas. Adapun identitas yang terbentuk adalah identitas hibrid, dalam arti, subjek yang terdapat dalam roman ini memiliki sifat yang ambigu sekaligus ambivalen. Hal ini tampak pada subjek Haji Serbanna, Imas, sedangkan identitas yang terbangun dalam diri Brani bersifat ambigu.
\end{abstract}

Kata kunci: ideologi, identitas, poskolonial

\section{IDEOLOGY AND IDENTITY OF SUNDANESE COMMUNITY IN THE CARIOS AGAN PERMAS ROMANTIC STORY OF JOEHANA'S LITERARY WORKS \\ (Poscolonial Criticism Approach)}

\begin{abstract}
This study aims to describe the ideology and identity of the Sundanese community which is reflected in the literary works, especially romance. Its description concerns with the influence and change of ideology and the causal effect identity of colonialism. In describing this study, the writer used Poscolonial Criticism Approach and descriptive-analytic method. Fokalisator and interpretation techniques were used to analyze the data. The analysis result of Carios Agan Permas romantic story shows that every social society class has different ideologies. For the rulling class, the ideology is used to maintain social cohesion and to strengthen the power. It is represented by the subject of Haji Serbanna and Imas. For the oppressed class, the ideology is used as a form of resistance. This form of ideology is present in Ambu Imba and Otong. In this romantic story there is also a rulling class ideology, but in practice it is used to carry out resistance and to protect the oppressed class. The formed identity is a hybrid identity, in a sense, the subjects in this romantic story have both ambiguous and
\end{abstract}


ambivalent caracter. The ambivalent character is seen in the subject of Haji Serbann and Imas, while the ambiguous caracter is found in Brani personality.

Keywords: ideology, identity, poskolonial

\section{PENDAHULUAN}

Terbentuknya sebuah masyarakat tentu tidak akan lepas dari ideologi yang dianutnya. Ideologi ini bisa diartikan sebagai gagasan dan pandangan hidup, baik sebagai individu atau sebagai suatu kelompok dalam memandang persoalanpersoalan yang dihadapi untuk mempertahankan keberlangsungan hidupnya ${ }^{1}$. Dalam Kamus Umum Bahasa Indonesia (2008), ideologi diartikan sebagai sekumpulan konsep bersistem dan atau cara berfikir seseorang atau segolongan kelompok.

Karl Marx dan Engels dalam bukunya The German Ideology, mengemukakan bahwa ideologi pada dasarnya adalah suatu kesadaran yang melenceng atau keliru atas dunia, kesadaran yang menyembunyikan hubungan riil orangorang dengan dunia mereka. Mereka menambahkan bahwa gagasan-gagasan tentang kehidupan kita berasal dari dunia di sekeliling kita, dan bahwa bukan kesadaran yang menentukan kehidupan kita tetepi kehidupan di sekelilingi kita yang menentukan kesadaran atau dengan kata lain ideologi terbentuk karena keadaan lingkungan kita (Loomba, 2003, hal. 33; Sianipar, 2008, hal. 22).

Sementara itu, Gramsci menarik perbedaan antar berbagai jenis ideologi, dengan mengemukakan bahwa ideologi itu pada umumnya bekerja untuk mempertahankan kohesi sosial dan mengekspresikan kepentingan-kepentingan dominan, terdapat juga ideologi-ideologi tertentu yang mengekspresikan protes dari mereka yang dieksploitasi. Dengan kata

\footnotetext{
1 Lihat dan bandingkan dengan buku Warnaen, Suwarsih, dkk. 1987. Pandangan Hidup Orang Sunda; Seperti Tercermin dalam Tradisi Lisan dan Tulisan. Bandung: Sundanologi. Hal. 164
}

lain, ideologi tiap masyarakat atau kelas mempunyai tujuan yang berbeda. Bagi kelas penguasa, ideologi bertujuan mempertahankan kohesi sosial dan kepentingan dominan. Sedangkan bagi kelas tertindas, ideologi merupakan ekspresi perlawanan dari masyarakat yang dieksploitasi (Loomba, 2003, hal. 37-39).

Mengingat hal di atas, maka setiap individu atau kelompok masyarakat pada hakikatnya tidak akan melepaskan diri ideologi yang dianutnya. Ideologi ini yang kemudian menciptakan tatanan masyarakat dengan berbagai produk kebudayaan, baik itu dari segi ekonomi, politik, sistem kepemerintahan, sistem sosial, termasuk bahasa dan sastra. Meski demikian, gagasan dan pandang hidup bukan berarti tidak mengalami perubahan. Perubahan ini bisa saja terjadi, salah satuhnya akibat adanya persinggungan ideologi dengan kelompok atau negara lain, misalnya melalui penjajahan.

Mengingat masyarakat Indonesia yang memiliki keberagaman suku, bukan tidak mungkin persinggungan ideologi ini sudah muncul sebelum kedatangan pemerintah kolonial Belanda. Ini bisa saja terjadi melalui peperangan antar kerajaan yang ada dikepulauan Indonesia. Contoh yang diambil adalah antar kerajaan Sunda dengan kerajaan Mataram. Meski belum pasti peperangan seperti apa, namun ini terlihat dari produk budaya Mataram yang sampai sekarang masih terasa. Pengaruh ini bukan hanya pada wilayah kesenian, tapi juga pada wilayah administrasi pemerintahan, gaya hidup, bahasa, dan kesusastraan. Salah satu contoh yang paling terkenal adalah wawacan ${ }^{2}$.

2 Lihat, Moriyama, 2013. Semangat Baru; 
Di samping itu, penjajahan pemerintah kolonial Belanda di Jawa, menjadi penting untuk dijadikan catatan. Bercokolnya kolonial Belanda kuranglebih 350 tahun tentu bukan waktu yang singkat untuk tidak merubah - atau lebah tepat disebut mageuhan - tatanan masyarakat yang sudah terbentuk sebelumnya. Meski demikian, gagasan dan pandang hidup seseorang atau kelompok tidak lantas mengalami perubahan secara total, melainkan terdapat pandangan yang tetap, bahkan memungkinkan terjadinya "pengawinan" antara cara pandang yang lama dengan yang baru, sehingga menghasilkan produk kebudayaan baru. Hal ini yang kemudian disebut identitas. Tapi identitas yang menjadi kajian dalam tulisan ini adalah identitas poskolonial, yang mana identitas ini sering dikaitkan dengan hibriditas. Hibriditas itu sendiri adalah cara untuk melihat interaksi antara budaya-budaya yang berbeda, yang satu saat akan menghasilkan pembentukan budaya-budaya dan identitas-identitas yang baru. Tapi yang menjadi pusat perhatian dalam konteks hibriditas, bukan pada persoalan produk budaya yang dihasilkan, tapi pada persoalan bagaimana cara menempatkan produk budaya yang dihasilkan dalam ruang sosial dan sajarah (Day dan Foulcher, 2008, hal. 12-13).

Konsep hibriditas sendiri dikenalkan oleh Homi K. Bhabha, yang berhasil menelaah relasi antar penjajah dan terjajah yang memperlihatkan adanya hubungan yang saling memengaruhi, saling memanfaatkan, dan saling melengkapi dalam mendukung masing-masing subjék, baik pihak penjajah maupun pihak yang terjajah. Menurut Bhabha, hibriditas sering berada pada ruang pengucapan ketiga (ruang antara), dalam arti identitas sering berada di wilayah yang kontradiksi dan ambivalensi. Dalam ruang antara ini,

Sunda abad ke-19. Jakarta: Komunitas Bambu. Edisi revisi. menurut Bhabha, terjadinya proses mimikri (dalam Darmawan, 2014, hal. 27).

Menurut Bhabha mimikri (dalam Sugiarti, 2005, hal. 41-42; Darmawan, 2014, hal. 28-29), adalah merupakan upaya untuk meng-copy subjek penjajah, yang dalam praktiknya tak sepenuhnya sama (as subject of difference, that is almost the same, but not quite). Menurut Bhabha konsep meniru ada pada ruang antara, sebab dalam satu sisi kaum pribumi berupaya untuk membangun identitas yang serupa dengan kaum penjajah, sedangkan merekapun sekuat tenaga mempertahankan perbedaan. Dalam praktiknya, mimikri tidak sebatas meniru, tapi juga merupakan upaya untuk menghina. Sikap menghina ini, merupakan cara pribumi dalam membedakan atau melawan kaum penjajah, antar rakyat kecil dengan penguasa. Selain itu, dalam prosés peniruan ini juga, selanjutnya akan membentuk identitas baru yang hibrid sebab-akibat dari bertemunya budaya dan ideologi antar penjajah dengan yang dijajah.

Berdasarkan permasalah di atas, akan menarik dan penting untuk membahas ideologi dan identitas masyarakat Sunda. Tapi dalam tulisan ini, tidak akan luas membahas bagaimana ideologi dan identitas masyarakat Sunda secara umum, melainkan hanya membahas cerminan kecil mengenai persoalan tersebut, dalam sebuah karya sastra Sunda berbentuk roman $^{3}$ terbitan tahun 1920-an. Satu diantara yang akan dibahasa adalah roman Carios Agan Permas karya Joehana.

Untuk dapat menguraikan hal tersebut, tulisan ini akan menggunakan pendekatan kritik poskolonial. Poskolonial

\footnotetext{
${ }^{3}$ Sengaja dalam penelitian ini istilah roman yang dipakai, bukan novel. hal ini merujuk pada pendapat Iskandarwassid (lihat Kamus Istilah Sastra) dan Ajip Rosidi (Mengenal Kesusastraan Sunda) yang dalam khazanah sastra Sunda istilah roman dan novel sama saja. Hal lainnya dikarenakan istilah roman pada saat itu lebih dikenal oleh kalangan masarakat Sunda.
} 
sendiri adalah pendekatan kritis dalam memahami efek-efek kolonialisme yang terus ada di dalam teks-teks sastra (Foulcher dan Day, 2008, hal. 3). Salah satu efek tersebut adalah ideologi dan identitas yang terbentuk sebab-akibat adanya kolonial. Namun yang menjadi persoalan adalah bukan bentuk ideologinya, tapi bagaimana gerak dan praktek ideologi. Dan apa saja yang membentuknya (lht. Jones, 2010, hal. 101). Berkaitan dengan itu, dalam tulisan ini juga digunakan pendekatan kritik ideologi hegemoni Antonio Gramsci.

Hegemoni itu sendiri adalah kekuasaan yang dicapai melalui kombinasi paksaan dengan kerelaan. Melalui pendekatan ini Gramsci mencoba menyatakan bahwa kelas-kelas berkuasa memperoleh dominasinya bukan dengan kekuatan dan paksaan saja, tetapi juga dengan menciptakan subjek-subjek yang "sukarela" untuk dikuasai (Takwin, 2009, hal. 74; Patria dan Arif, 2009, hal. 119; Simon, 2004, hal. 21-22). Dengan demikian Gramsi memandang ideologiideologi itu bukan hanya sekedar refleksirefleksi dari realitas material, melainkan merupakan konsepsi-konsepsi kehidupan yang tampak dalam semua aspek eksistensi individual dan kolektif. Dengan kata lain, Gramsci mencoba menyelami bagaimana ideologi-ideologi menggerakan hubunganhubungan sosial, mengorganisasi masa, memperoleh kesadaran, perjuangan, dan sebagainya (Loomba, 2003 hal 38-39; Simon, 2004, kc. 82-83; Faruk, 2012 hal 131-137).

\section{METODE}

Metode yang digunakan dalam penelitian ini adalah metode deskriptif analitik yang bertujuan untuk mencari dan mendeskripsikan data-data dengan mengaitkan antara struktur sosial dengan teks sastra secara teliti (Ratna, 2009 hal. 53). Adapun yang disebut fakta-fakta dalam tulisan ini adalah data tentang pangaruh dan akibat-akibat kolonialisme yang salah satunya adalah bentuk ideologi dan identitas. Untuk mengungkap persoalan tersebut, penulis menggunakan pendekatan kritik sastra poskolonial. Adapun untuk menganalisis data digunakan teknik fokalisator dan teknik interpretasi, sedangkan untuk mengumpulkan semua kebutuhan terkait dengan sumber data dan data digunakeun teknik studi pustaka.

\section{HASIL PENELITIAN DAN PEMBAHASAN}

\section{Ideologi dan Praktik Idiologi: Dominasi dan Resistensi Kelas Sosial}

Ideologi yang menjadi pembahasan dalam tulisan ini, bukan pada persoalan ideologi sebagai gagasan politik, tapi ideologi yang menurut Gramsci sebagai kerangka kerja mental, keyakinankeyakinan, konsepsi-konsepsi kehidupan yang tampak dalam aspek eksisténsi individu dan kolektif. Oleh sebab itu, ideologi mempunyai makna yang luas, bukan hanya sebagai sistem ide dan refleksi-refleksi dari realitas material, tapi lebih jauh dari itu. Ideologi bisa menggerakkan dan mengatur hubunganhubungan sosial, mengorganisir masyarakat, dan memosisikan manusia untuk mendapatkan kesadaran akan posisi dirinya, perjuangannya, dll (Loomba, 2003, kc. 39; Simon, 2004, kc. 82-83; Faruk, 2012 hal 131-137).

Berkaitan dengan hal di atas, ideologi sering digunakan oleh setiap kelas sosial untuk mendominasi dan meresistensi terhadap kenyataan sosial yang lahir di masyarakat. Tapi munculnya kelas sosial yang mendominasi dan meresistensi lebih disebabkan oleh faktor ekonomi. Persoalan ekonomi yang selanjutnya menggerakkan kesadaran setiap kelas untuk berupaya mendominasi atau meresistensi kelas sosial lainnya. Intinya, ideologi kelas sosial sangat terpengaruhi oleh banyak tidaknya 
kekeyaan setiap kelas itu sendiri. Jika kita melihat pada roman Carios Agan Permas, persoalan seperti itu sangat tampak. Apa yang ditunjukkkan oleh kelas sosial Haji Serbanna, menjadi bukti nyata. Haji Serbanna yang sebelumnya merupakan masyarakat kelas biasa, akhirnya menjadi masyarakat kelas kuasa. Kekuasaan Haji Serbanna diperoleh ketika ia menjadi orang kaya. Haji Serbanna menganggap dirinya penguasa sebab-akibat banyanya harta-benda. Dengan kekayaannya Haji Serbanna bisa dengan leluasa dan bebas melakukan segala cara untuk mendapatkan apa yang ia inginkan. Kesadaran seperti itu muncul dari adanya anggapan bahwa yang kaya berkuasa dan bisa membeli segalanya.

Munculnya anggapan tersebut sebetulnya tidak bisa dilepaskan dari pengaruh penjajahan kolonialisme Éropa, yang membawa gagasan liberalisme, terutama ketika diterapkannya sistem sewa tanah. Dan secara tidak langsung pengaruh tersebut memunculkan konsep baru dalam hal penguasa. Jika sebelumnya (waktu prakolonial), yang disebut penguasa ditentukan oleh banyak-tidaknya golongan cacah yang dimiliki oleh menak, setelah masuknya liberalisme berubah, yang menentukan seseorang berkuasa atawa tidak dilihat dari banyak-tidaknya harta benda (lht. Breman, 2014, hal. 33 dan hal. 118; Hardjasaputra, 2004, hal. 29). Melalui jalan yang kedua, seorang Haji Serbanna mendapat kekuasaannya.

Meningkatnya kelas sosial Haji Serbanna, kemudian memunculkan kesadaran dan gagasan-gagasan dirinya untuk mendominasi kelas sosial lainnya. Misalnya yang tampak pada nasib kelas sosial Bapa dan Ambu Imba. Bapa dan Ambu Imba yang secara kelas sosial berada dibawah Haji Serbanna kemudian menjadi korban kekuasaan dan dominasi Haji Serbanna. Bapa dan Ambu Imba, menjadi kelas tertindas sebab-akibat praktik dominasi Haji Serbanna. Adapun praktik dominasi yang dilakukan oleh Haji Serbanna tiada lain, tiada bukan untuk mempertahankan kohesi sosialna dan untuk melanggengkan kekuasaannya. Dalam hal ini oleh Haji Serbanna, ideologi digunakan atau diterapkan untuk mendominasi kelas sosial lainnya.

Dominasi Haji Serbanna sendiri dimulai ketika dia menjadi rentenir dan menjadi rajakaya di kampungnya. Bukan hanya itu, untuk mempertahankan kohesi sosial agar dirinya tetep dipandang sebagai Haji (patuh pada ajaran islam), dia tidak segan-segan memelintirkan konsep agama. Ini tergambar ketika bapa Imba meminjam uang pada Haji Serbanna dengan perjanjian bapa Imba akan membayar dengan rentennya. Namun Haji Serbanna berkilah, bahwa renten itu dosa. Dan dia mengganti kata renten dengan kalimah pamulang tarima lantaran ditulung keur di jero kasusas (sebagai ucapan terimakasih, karena telah ditolong dalam keadaan susah), begitu juga ketika bapa Imba mengatakan rumah sebagai 'tebusan' jika tidak bisa bayar, Haji Serbanna mengganti kata tersebut dengan 'menjual'. (Joehana, 1996, hal. 24-25).

Dalam hal ini ada dua cara pandang yang ditunjukan oleh Haji Serbanna, satu sisi dia sebagai seorang rentenir, yang sudah jelas menggunakan cara paksaan untuk mempertahankan kekuasaanya sebagai juragan. Dan di sisi lain dia juga mencoba untuk menciptakaan kerelaan, melalui konsep agama dan bahasa yang ia kuasai. Ini memperlihatkan bahwa Haji Serbanna memperadukkan konsep agama, moral, kehidupan sosial, secara bebas (liberal) demi mempertahankan kekuasaan dan kohesi sosialnya.

Dalam hal lain (masalah gender) gagasannya muncul ketika dia ingin menikahi Imas, anaknya bapa Imba. Keinginan menikahi Imas, berawal dari kematian bapa Imba dan ketidak mampuan membayar utang serta paksaan Haji Serbanna pada ambu Imba, melalui 
ancaman hukuman penjara, yang akhirnya ambu Imba merelakan Imas untuk dikawinkan sebagai ganti utang pada Haji Serbanna. Namun Haji Serbanna yang tidak ingin melanggar aturan ajaran agamanya, yang tidak membolehkan lakilaki memiliki lebih dari empat istri, kemudian tidak lantas menikahi Imas. Dia mencari jalan keluar dengan menyuruh Otong bujangnya untuk menikahi Imah, namun tetap Imas menjadi istrinya Haji Serbanna (Joehana, 1996, hal. 45).

Tapi perlawanan muncul, diwakili oleh kohesi sosial (menak dan bujang) yang tidak menjajah dan terjajah, seperti direpresentasikan oleh Otong dan Haji Serbanna. Dengan memanfaatkan kedekatan Otong dengan Haji Serbanna, dan kelemahan Otong sebagai budak, menjadi kekuatan tersendiri untuk memperoleh kesadaran dan melakukan perlawanan terhadap penjajahan. Selain itu, perlawanan itu sendiri tidak lepas dari gagasannya tentang moralitas yang tidak sepakat dengan tindakan Haji Serbanna yang mirip dengan binatang (Joehana, 1996, hal. 52-53). Perlawanan lain muncul oleh yang terjajah, seperti direpresentasikan oleh Ambu Imba, yang pada akhirnya melawan penjajahan Haji Serbanna, dengan cara membakarnya.

Hal serupa tampak pada subjek Imas. Imas yang sebelumnya merupakan rakyat biasa, bahkan secara status sosial lahir dari golongan cacah, pada akhirnya menjadi menak dan status kelas sosialnya meningkat. Meningkatnya status sosial Imas tidak lepas dari perkawinannya dengan Tuan Van der Zwak, seorang Tuan Kuasa di perkebunan. Dalam hal ini tampak adanya relasi antar ras Pribumi dengan Eropah. Relasi ini sebenarnya tidak lepas dari pengaruh wacana kolonialis, tentang hukum perkawinan antar bangsa Eropah dengan Pribumi (lht. Suyono, 2005, hal. 22).

Perlu dicatat, meningkatnya status sosial Imas tidak lepas dari faktor perekonomian. Imas yang lahir sebagai orang miskin, akhirnya menjadi kaya karena menikah dengan orang kaya. Melalui jalan tersebut Imas kemudian menjadi penguasa. Namun kekuasaaan yang didapat oleh Imas kemudian tidak melahirkan kesadaran kelas sosial untuk membela bangsanya sendiri, yang pada saat itu sedang terjajah oleh Belanda. Imas lebih memilih kesadarannya untuk menganiaya bangsanya sendiri. Melihat hal ini, kesadarana yang lahir menyebabkan Imas mendominasi kelas sosial lainnya. Dalam hal ini juga ideologi yang dianut oleh Imas dipraktekkan untuk mempertahankan kohesi sosial dan juga memperkuat kekuasaannya.

Tapi kesadaran untuk menjadi penguasa, sebelumnya sudah muncul dalam diri Imas, tepatnya Imas masih berada dalam posisi kelas sosial rendah, namun dalam praktiknya, Imas tidak mampu mendominasi kelas sosial lainnya, sebab ia tidak mempunyai mekanisme/ cara/alat (sebab tidak kaya) untuk menggerakan atau menerapkan gagasangagasan dirinya untuk menguasasi, yang ada ia meresistensi akan keadaan dirinya yang miskin. Baru setelah Imas melakukan relasi melalui perkawinan dan menjadi orang kaya, gagasan untuk mendominasi terlaksana. Hal ini menunjukan bahwa ideologi bagi imas bukan hanya ada di wilayah kesadaran, tapi juga di wilayah praktik kerja.

Tapi perlu disampaikan juga, meski Imas menjadi seorang penguasa yang mendominasi, pada puncaknya - di mana Imas berada diambang kematian-ia tersadarkan. Imas mengakui dan menyesali akan perbuatannya (Joehana, 1996, hal. 182-183). Kesadaran ini juga menunjukan pengakuan dirinya sebagai Imas seorang pribumi, sebagai anak dari petani.

Bentuk ideologi lainnya digambarkan oleh subjek Otong dan Ambu Imba. Secara status sosial Otong dan Ambu Imba berada diposisi kelas bawah yang tertindas. Tapi 
karena dominasi Haji Serbanna yang semakin kuat dan menindas kemudian perlawanan muncul. Perlawanan yang dilakukan oleh keduanya berbeda. Misalnya Otong, resistensi yang dilakukan olehnya berangkat atau muncul akibat kesadaran Otong yang tidak menerima dengan peristiwa dan tindak aniaya Haji Serbanna dalam merpertahankan kohesi sosialnya. Hal ini terlihat, ketika Haji Serbanna mengintimidasi keluarga Imba dan berusaha memperkosa Imas. Otong dengan sadar melawan Haji Serbanna, meski secara sosial ia adalah pembantu Haji Serbanna yang "seharusnya" patuh pada majikannya. Adapun resistensi yang dilakukan oleh Ambu Imba muncul karena perbuatan Haji Serbanna yang semakin menindas. Sebab-akibat dari paksaan dan penganiayaan terhadapnya, pada akhirnya muncul kesadaran untuk melawan, bentuk perlawanan itu sendiri dilakukan dengan cara membakar Haji Serbanna.

Berbeda dengan subjek Brani. Sebelum Brani diasuh oleh Tuan W.J. Human, Brani merupakan seubjek yang teraniaya dan berada di kelas sosial bawah. Brani menjadi korban kekuasaan Haji Serbanna, meski dalam cerita ini perlakuan Haji Serbanna pada Brani tidak langsung terjadi, tapi akibat perbuatan Haji Serbanna yang menculik Imas, ibunya, jadi sebabmusabab Brani jadi subjek teraniaya. Brani dan ayahnya harus hidup dalam penderitaan selama di Batavia. Tapi setelah Brani diasuh dan disekolahkan oleh bangsa Belanda yang bernama Tuan W.J. Human, kehidupan Brani berubah, begitu juga dengan cara berfikirnya menjadi lebih maju.

Cara berfikir Brani yang maju sejatinya sudah muncul sejak ia kecil, sebelum ia bertemu dengan Tuan W.J. Human. Hal ini terpengaruhi oleh proses pendidikan dari ayahnya, karenanya cara berfikir Brani sudah tampak seperti orang dewasa. Tapi tidak cukup dengan itu, untuk mengembangkan, menerapkan, dan menggerakkan kesadarannya, Brani tetap membutuhkan mekanisme lainnya, seperti ia harus sekolah di sekolah Eropa dan menjadi anak orang kaya-setidaknya itu yang ada dalam cerita. Brani sadar hanya dengan jalan itu, ia akan mampu menggerakkan kesadarannya untuk memihak dan membela rakyat pribuminya (Joehana, 1996, hal. 132). Hal ini menandakan bahwa ideologi bagi Brani bukan hanya pada wilayah kesadaran, tapi juga pada wilayah praktik kerja atau cara menerapkan kesadaran untuk merubah tatanan masyarakat yang tertindas. Adapaun kesadaran itu muncul ketika ia telah mengenyam pendidikan Eropa. Kondisi tersebut, yang pada akhirnya merubah status kelasnya dan memengaruhi pada penerapan ideologi yang ada dalam pikirannya.

Jika melihat peristiwa di atas dan mengaitkannya dengan sejarah penjajahan yang dirasakan oleh masyarakat Sunda khususnya. Maka akan tergambar sebuah perubahan mengenai konsep kelas sosial. Misalnya ketika masa penjajahan prakolonial, perubahan atau peningkatan status kelas sosial dipengaruhi oleh banyak-tidaknya kaum cacah yang dimiliki oleh kelas sosial lainnya, dalam masa penjajahan kolonialis VOC dan Belanda yang merubah status sosial seseorang dilihat dari banyak-tidaknya harta-benda yang dimiliki oleh suatu kelas sosial, dan yang terakhir ketika masa penjajahan kolonialis Belanda akan berakhir, yang merubah kelas sosial seseorang adalah dengan cara mengenyam pendidikan Eropa/tinggi (lht. Breman, 2014, hal. 33; Hardjasaputra, 2004, hal. 29; Niel, 2009, kc. 82; Smit, 2005, kc. 87).

\section{Identitas dalam Roman Carios Agan Permas}

Munculnya identitas seseorang tentu tidak lepas dari persoalan ideologi yang dianutnya. Hal ini berkaitan dengan cara berfikir subjek dalam merefleksikan 
realitas hidup yang selanjutnya menjadi identitas dari subjek tersebut. Tapi yang menjadi persoalan selanjutnya bagaimana subjek tersebut menempatkan identitas dirinya dalam ruang sosial masyarakat. Seperti halnya Haji Serbanna yang menerapkan ideologi sebagai bentuk dominasi dan menindas, tentu identitas yang dibentukpun diperlukan untuk mempertahankan kohesi sosial dan mempertahankan kekuasaannya. Hal ini tergambar dari cara praktik kerjanya. Misalnya ketika ia menjadi "haji" yang secara pandangan umum haji merupakan identitas yang menunjukan pada seseorang yang taat akan ibadah. Namun ieu gunakan sebagai tameng atas tindakannya yang ingin mempertahankan kohesi sosialnya. Selain persoalan itu, identitas juga muncul akibat adanya proses mimikri dari subjek lainnya, misalnya Haji Serbanna meniru menak bupati, dalam hal perkawian, gaya hidup, dan bahasa (menggunakan tingkatan) $)^{4}$.

Dalam kohesi sosial antara pribumi dan Belanda terlihat ada dua relasi yang berbeda, pertama direpresentasikan oleh Imas dan Tuan van der Zwak. Kedua direpresentasikan oleh Brani dan Tuan Human. Dalam hal ini, pengarang seakan ingin menekankan aspek kepribumian tokoh Imas dan Brani dalam melakukan dominasi dan resistensi. Dominasi tersebut bisa dilihat dari identitas ras Imas, yang memilih "orang lain" (barat) ketimbang kepribumiannya. Ini ditunjukan dengan pernikahan Imas dengan Tuan van der Zwak-setelah sebelumnya Ia pun memilih menjadi menak.

Hal lain ditunjukan ketika Imas mengusir ibunya. Demi usahanya untuk menutupi dan mempertahankan kohesi sosial sebagai menak dan nyonya Belanda, Imas dengan tegas tidak mengakui ibunya dan secara tidak langsung ia tidak

\footnotetext{
${ }^{4}$ Lihat dan bisa dibandingkan dalam Buku Nina $\mathrm{H}$. Lubis. Kehidupan Kaum Menak Priangan 18001942 (1998) Bandung: Pusat Informasi Sunda.
}

mengakui kepribumiannya. Memang identitas "orang lain" yang ditunjukan Imas sudah tampak ketika ia masih remaja. Ketika sering bergaya ala menak dan sering memimpikan menikah dengan seorang menak (Joehana, 1996, hal. 21). Hal tersebut berlanjut, ketika ia menjadi Nyonya van der Zwak. Ini terlihat dari cara pergaulannya, ketika ia mengikuti adat barat dengan mengadakan pesta dansa (dans partij). Begitu juga dengan cara berbicaranya yang sering menggunakan bahasa Belanda (Joehana, 1996, hal. 8689). Tapi perlu disampaikan, terutama ketika Imas berada diambang kematiannya. Kesadaran akan kepribumuannya muncul. Ini ditunjukan dengan pengakuan dan penyesalan Imas akan segala perbuatannya (Joehana, 1996, hal. 182-183). Kesadaran ini juga menunjukan pengakuan dirinya sebagai Imas seorang anak dari petani.

Di lain sisi relasi antara Brani dan Tuan Human menciptakan resistensi yang dilakukan oleh Brani dan tanpa merubah identitas kepribumiannya. Ini dimulai ketika Brani diangkat menjadi anak Tuan Human, dan iapun mendapat pendidikan kolonial. Namun sangat disayangkan dalam roman ini, resistesi dan identitas ras Brani tidak banyak terlihat. Hanya ditunjukan pada bagian terakhir cerita, itu pun diceritakan hanya untuk keperluan saja.

Gancang carita, sarta dijojo pereluna baé, Brani eureun digawéna, rajakayana nu teu saeutik téh dipaké nyieun rumah-rumah miskin, sakola-sakola miskin jeung barudak pahatu, rumah sakit keur nu mariskin jeung jaba ti éta. Nepi ka manéhna mah hirup basajan baé.

(Singkat cerita, dan hanya untuk keperluan saja, Brani berhenti bekerja, kekayaannya yang melimpah digunakan untuk membuat rumahrumah miskin, sekolah-sekolah miskin dan anak-anak yatim-piatu, 
rumah sakit untuk orang-orang miskin dan banyak lagi. Sementara itu dia hidup dengan sederhana).

Meskipun hanya digambarkan di akhir cerita, tokoh Brani menjadi sosok yang humanisme yang patut ditiru dan seolah-olah pengarang ingin menegaskan, menyadarkan, mengajak pembaca untuk mengikuti jejak Brani. Hal ini juga dipertegas oleh keterangan pengarang dalam kalimah selanjutnya.

Upama Anjeun datang kana vergadering $n u$ enya-enya rék mikanyaah ka nu malarat, di dinya Anjeun bakal kapanggih jeung...Brani.

(Jikalau anda datang dalam sidang ${ }^{5}$ yang bertujuan untuk menyayangi rakyat kecil, di sana anda akan bertemu dengan...Brani)

Apa yang dikerjakan Brani dalam memanfaatkan pengaruh kolonial untuk menjadi dasar dirinya dalam membela rakyat, tentu menjadi semangat nasionalisme dirinya. Brani sadar jikasebagai orang yang tahu lebih-dirinya harus memihak pada kaum tertindas. Bagi Brani kekuasaan tak ada artinya jika tidak digunakan untuk menolong sessam. Cara berfikir Brani mengingatkan pada cara berfikir Y.B Mangunjaya. Mangunjaya (dalam Foulcher, 2008, kc. 19), menegaskan:

"Para pemimpin generasi SukarnoHatta masih harus bergulat dulu, belajar dan memperjuangkan suatu bahasa nasional sesudah mereka dikuasai oleh bahasa Belanda, Inggris, Jerman, dan Prancis, akan tetapi justru berkat penguasa bahasabahasa asing itulah mereka mampu berbicara-berfikir modern yang mutlak diperlukan untuk ber-

\footnotetext{
5 Berdasarkan keterangan bahasa Belanda yang terdapat dalam novel Carios Agan Permas.
}

komunikasi pada taraf internasional demi pemerdekaan bangsa".

Cara berfikir Brani sejatinya menjadi identitas dirinya. Adapun perbuatan yang dilakukan oleh Brani yang selanjutnya disebut hibriditas. terakhir, mengidentifikasi diri dan sang lain, bisa menjadi hal yang penting untuk hirup di masyarakat. Hal ini dilakukan untuk menghindari jurang pemisah antara individu dengan individu lainnya yang berbeda dalam hal identitas. Dalam arti, adanya berbedaan identitas itu tidak harus menciptakan penindasan, penganiayaan, dan eksploitasi pada individu yang identitas sosialnya lebih rendah. Dalam hal ini, kita perlu bercermin pada pendapat Sen (2007, kc. 26-27), yang menyebutkan bahwa kepentingan satu identitas tidak seharusnya menegasikan kepentingan identitas lainnya.

\section{PENUTUP}

Setiap individu atau kelompok masyarakat tidak melepaskan diri dari ideologi yang dianutnya, begitu juga dengan masuknya kolonialisme ke tanah jajahan, yang membawa ideologi, dan dijalankan dengan sistematis serta melibatkan seluruh aspek kehidupan, bukan tidak mungkin pengaruh dari ideologi yang dibawa oleh kolonialisme bercokol langgeng daripada penjajahan itu sendiri. Diperkenalkannya pendidikan, sastra terjemahan, budaya cetak, dan kebijakan-kebijakan politik kolonial yang memuat ideologi barat menjadi bukti sahih bagaimana pengaruh kolonialisme masih terasa sampai sekarang. Pengaruh tersebut bukan hanya di wilayah politik dan ekonomi saja, tapi juga wilayah lainnya. Di wilayah sastra, jika kita memandang sastra merupakan cerminan masyarakat, tentu roman menjadi representasi kecil bagaimana ideologi menggerakan hubungan-hubungan kehidupan sosial, dan memunculkan kesadaran. Seprti yang 
tampak pada roman Carios Agan Permas karya Joehana. Tokoh Haji Serbanna sebagai tokoh yang memiliki gagasan liberalisme, dan lahir sebagai tokoh yang memiliki kohesi sosial penguasa selanjutnya menciptakan hubungan sosial yang menindas atas kaum proleter. Sedangkan otong yang mewakili gagasan sosialis, mencoba melakukan perlawanan dan membela rakyat tertindas. Di sisi lain Brani juga meunjukan sikap yang nyaah pada rakyat miskin, dengan membangun berbagai fasilitas yang diperuntukan untuk orang-orang miskin. Dalam roman ini juga terdapat dua identitas yang berbeda. Ini terlihat dari tokoh Imas dan Brani. Imas yang sejatinya lahir sebagai seorang cacah, setelah perkawinnya dengan Tuan van der Zwak, ia memilih menjadi "orang lain,"meski pada akhir hidupnya Imas sadar akan kepribumiannya - sedangkan Brani yang juga bersinggungan dengan Belanda (menjadi anak asuh Tuan Human dan berpendidikan Belanda), tapi justru ia tetap menjadi seorang pribumi yang kemudian sadar untuk membela rakyat miskin. Sebagaimana telah disebutkan bahwa ideologi tidak selamnya tetap, melainkan mengalami perubahan, dengan adanya pengaruh (bc: penjajahan) ideologi dari luar. Tentu di sini terjadi pergulatan ideologi yang kemudian menciptakan berbagai produk kebudayaan dan juga mempengaruhi pada identitas seseorang atau kelompok masyarakat. Dan apa yang ada dalam roman Carios Agan Permas, sedikitnya menjadi representasi pergulatan tersebut.

\section{DAFTAR RUJUKAN}

Breman, Jan. (2014). Keuntungan Kolonial dari Kerja Paksa: Sistem Priangan dari Tanam Paksa Kopi di Jawa 1720-1870. Jakarta: Yayasan Obor Indonesia.

Darmawan, Darwin. (2014). Identitas Hibrid Orang Cina. Yogyakarta: Gading Publishing.
Departemen Pendidikan Nasional. 2008. Kamus Umum Bahasa Indonesia. Jakarta: Pusat Bahasa.

Faruk. (2012). Pengantar Sosiologi Sastra; dari Strukturalisme Genetik smpai Post-modernisme edisi revisi. Yogyakarta: Pustaka Pelajar.

Foulcher, Keith \& Tony Day. (2008). Sastra Indonesia Modern Kritik Postkolonial. Jakarta: Yayasan Obor Indonesia \& KITLV.

Hardjasaputra, A. Sobana. (2004). Bupati di Priangan: Kedudukan dan Perannya pada Abad ke-17 - Abad ke-19. Dimuat dina Seri Sundalana 3. Bandung: Yayasan Pusat Studi Sunda.

Joehana. (1996). Carios Agan Permas. Jakarta: Girimukti Pasaka.

Jones, Pip. (2010). Pengantar Tiori-Tiori Sosial: dari Teori Fungsionalisme hingga Post-modernisme. Jakarta: Yayasan Pustaka Obor Indonesia.

Loomba, Aina. (2003). Kolonialime/ Pascakolonialisme. Yogjakarta: Bentang Budaya.

Niel, Robert van. (2009). Munculnya Elit Modern Indonesia. Bandung: Pustaka Jaya.

Patria, Nezar \& Andi Arif. (2009). Antonio Gramsci Negara \& Hegemoni. Yogyakarta: Pustaka Pelajar.

Sen, Amartya. (2007). Kekerasan dan Ilusi Identitas. Serpong: Marjin Kiri.

Simon, Roger. (2004). Gagasan-gagasan Politik Gramsci. Yogyakarta: Pustaka Pelajar.

Smit, Linda Tuhiwai. (2005). Dekolonisasi Metodologi. Yogyakarta: InsistPerss

Sugiarti, Yati. (2005). Identitas Dan Mimikri Dalam Roman Salah Asuhan Karya Abdoel Moeis. UNY: Tesis.

Suyono, Capt. R. P., (2005). Seks dan Kekerasan Pada Zaman Kolonial; Penelusuran Kepustakaan Sejarah. Jakarta: Grasindo. 
Ratna, Nyoman Kutha. (2009). Teori, Metode, dan Teknik Penelitian Sastra. Yogyakarta: Pustaka Pelajar.

Takwin, Bagus. (2003). Akar-Akar Ideologi; Pengantar Kajian Konsep Ideologi dari Plato hingga Bourdieu. Yogyakarta: Jala Sutra.

\section{UCAPAN TERIMAKASIH}

Saya ucapkan terimakasih pada Allah Swt. yang terus memberikan nikmat sehingga tulisan ini rampung dikerjakan. Terima kasih pada seluruh dosen Prodi. Pendidikan Bahasa dan Budaya Sunda, terutama pada Dr. Retty Isnendes, M.Hum. yang memberi masukan perihal jurnal ini. Terima kasih juga saya ucapkan kepada tim penyunting Jurnal Lokabasa yang telah memuat tulisan ini. 